\title{
Industry 4.0 Implementation in US Primary Wood Products Industry
}

\section{Implementacija industrije 4.0 u primarnoj preradi drva u SAD-u}

\author{
Original scientific paper • Izvorni znanstveni rad \\ Received-prispjelo: 7. 4. 2020. \\ Accepted-prihvaćeno: 14. 1. 2021. \\ UDK: $630 * 832.1$ \\ https://doi.org/10.5552/drvind.2021.2017
}

\author{
(C) 2021 by the author(s) \\ Licensee Faculty of Forestry and Wood Technology, University of Zagreb. \\ This article is an open access article distributed \\ under the terms and conditions of the \\ Creative Commons Attribution (CC BY) license.
}

\begin{abstract}
Understanding barriers to implementation of Industry 4.0 strategies is a first step to enable companies to begin to use and implement new technologies; using new technologies will allow mills to improve efficiency and stay relevant in the face of increasing international competition. This study uses a mail survey to gather insights regarding awareness of technologies within the US primary wood products industry as well as the barriers to using new technologies. Awareness of technologies is generally low, especially with respect to additive manufacturing, autonomous systems, and big data. Lack of skilled workers is the primary limiting factor to implementation of new technologies with other key factors being out-of-date facilities and unclear financial benefits. Existing expertise was highest in manufacturing process monitoring and data analysis, and lowest in robotics. Only a very small group of respondents have already implemented any form of robotics. Overall, only six respondents (6.7\%) have an Industry 4.0 strategy, while 77 \% did not recognize the terms "Industry 4.0" or "Smart Manufacturing." Results suggest considerable room for additional application of I4.0 technologies in the industry.
\end{abstract}

Keywords: industry 4.0; wood products; digitalization; technology

\begin{abstract}
SAŽETAK • Razumijevanje prepreka za implementaciju strategija industrije 4.0 prvi je korak koji će omogućiti tvrtkama uvođenje i primjenu novih tehnologija. Uvođenjem tih novih tehnologija pilane će poboljšati svoju učinkovitost uz zadržavanje konkurentnosti. Ovo se istraživanje temelji na poštom upućenoj anketi kako bi se dobio uvid u svjesnost o tehnologijama u industriji primarne prerade drva u SAD-u, kao i o preprekama za primjenu novih tehnologija. Svjesnost o tehnologijama općenito je niska, posebice za aditivnu proizvodnju, autonomne sustave $i$ velike baze podataka. Nedostatak kvalificiranih radnika najveći je ograničavajući faktor za primjenu novih tehnologija, a ostali su otežavajući činitelji zastarjela postrojenja i nejasnoće o financijskim koristima što ih donosi primjena novih tehnologija. Najveća je stručnost zabilježena u području praćenja proizvodnih procesa i analizi podataka, a najmanja u robotici. Samo je vrlo mala skupina ispitanika već primijenila neki od oblika robotike. Ukupno samo šest ispitanika (6,7\%) ima strategiju Industrije 4.0, dok 77 \% ispitanika nije prepoznalo pojmove ,industrija 4.0“ ili „pametna proizvodnja“. Rezultati pokazuju da postoji znatan prostor za dodatnu primjenu tehnologija Industrije 4.0 u primarnoj preradi drva.
\end{abstract}

Ključne rïječi: Industrija 4.0; proizvodi od drva; digitalizacija; tehnologija

${ }^{1}$ Authors are researchers at Oregon State University, Corvallis, Oregon, USA. 


\section{INTRODUCTION}

\section{UVOD}

Similar to other manufacturing industries, the wood processing industry has undergone rapid changes in recent years. Developments among a host of technologies in manufacturing are making possible advancements to a new era, often referred to as the fourth industrial revolution. Even though it is an omnipresent topic in the media, there are still many obscurities due to the lack of a set definition of the term itself. While referred to as "Industry 4.0" in Europe, the phrase "Smart Manufacturing" is more common in North America (Thoben et al., 2017). Throughout the remainder of the text "I4.0" is used.

There is a discrepancy between the promoted image of the technological revolution associated with I4.0 and the real impact on today's companies. I4.0 can be defined as, "technological evolution from embedded systems to cyber-physical systems" (CPSs) (MacDougall, 2014), where CPSs are sensors, machines, workpieces or IT systems, which are connected within a manufacturing facility and/or along the value chain and able to interact with each other by the use of internetbased protocols. According to Jäger and Lerch (2020), CPSs are, “...intended to help plan, design and steer production systems and complete value-added networks by implementing intelligent horizontal and vertical digital networking in the value-added processes."

The transformation to I4.0 is taking place via: Autonomous robots, simulation, horizontal and vertical system integration, the Industrial Internet of Things (IIoT), Cybersecurity, the cloud, additive manufacturing, augmented reality and big data and analytics (Rüßman et al., 2015). Many of these technologies are already used in modern businesses, but in the course of I4.0 these individual elements from the physical and virtual world will interconnect to form a fully integrated and automated production system. These core elements of I4.0 enable gathering and analyzing data across machines, which allows for faster, more flexible and more efficient processes; production with decentralized, intelligent systems makes it possible to produce higher-quality goods at reduced costs, which in turn increases overall manufacturing productivity.

The need to implement new digital technologies results from various ongoing challenges. The globalization of markets has resulted in constantly increasing competition, while at the same time consumer demand is increasing for customized, yet, inexpensive products. Customization entails a growing number of variants and increasing complexity in the entire production process, ultimately resulting in a production batch size of one. This requires the use of automation and interconnected systems because the overall aim is to produce as economically as possible, including resource efficiency and short processing times. At the same time, changing demographics translate to a shortage of skilled labor and in turn increases the need for automated and intelligent processes. In order to continuously improve production processes, real-time data for all manufacturing elements is vital. In a smart factory, each part of the production system is monitored and automatically optimized/adjusted. This data collection provides vital information needed for process improvement. For instance, bottlenecks can easily be identified, production flows can be reorganized if necessary, the reliability of single machines and the whole plant can be calculated via downtimes, or short- and long-term production planning can be facilitated.

Naturally, I4.0 developments have also been affecting the wood processing industry. This industry is positioned in a market context of increasing international competition and steadily increasing pricing pressure. In this setting, it becomes vital - especially for smaller companies - to work as effectively, efficiently and economically as possible. In the near future it arguably will be crucial for companies to take advantage of I4.0 to improve innovativeness and maintain competitiveness (Kropivšek and Grošelj, 2020; Jäger and Lerch, 2020). As examples of early implementation of I4.0 tools, robots are becoming more common within wood products manufacturing as are advanced monitoring capabilities enabled via the Internet of Things.

This work focuses on assessing the current situation of the US primary wood products industry to obtain a comprehensive overview of the implementation of I4.0 elements and inhibiting factors within this process. The overall objectives are to:

- Identify the state-of-the-art in the US primary wood products manufacturing industry with respect to implementation of advanced manufacturing techniques and technologies.

- Identify hurdles to the adoption of advanced manufacturing techniques and technologies.

\section{BACKGROUND}

\section{DOSADAŠNJA ISTRAŽIVANJA}

I4.0 is the most recent generation of industrial evolution. The first industrial revolution was the mechanization and use of steam power in manufacturing, followed by mass production and the use of electricity $\left(2^{\text {nd }}\right)$, and flexible automation and the use of computers $\left(3^{\text {rd }}\right)$. We are currently in the fourth industrial revolution based on cyber physical systems (Basl, 2017), including the use of artificial intelligence, robotics, and other new technologies. Extensive digitalization is necessary for a manufacturing site to fully implement an I4.0 strategy. There is huge potential for integration of systems towards a more fully automated production process. However, there has been limited work thus far investigating I4.0 in forestry and wood products. Advanced technologies have been employed across the sector for some time. For example, cut-to-length harvest systems with advanced sensing and links to digital maps and mill order files have been commonplace for some time. Still, awareness of I4.0 and use of the term is rather limited (Müller et al., 2019). Similarly, in the wood products manufacturing sector, vision and sensing systems (e.g., 3D scanning of logs and lumber coupled with software to optimize yields), remote monitoring for preventive 
maintenance, and automation (e.g., for material handling, detecting and repairing defects in veneer, grading lumber, etc.) are increasingly commonplace in $21^{\text {st }}$ century manufacturing operations. Among a number of manufacturing sectors, wood, paper, and printing was the least $\mathrm{I} 4.0$ ready within the Upper-Rhine region of Europe (Jäger and Lerch, 2020). On the other hand, "full" implementation of I4.0 is rare in any sector (Flores et al., 2018, Schröder, 2017).

High technology costs and lack of skilled workers are key hurdles to further implementation of I4.0 in the wood products sector (Buehlmann et al., 2020; Kropivšek and Grošelj, 2020; Ratnasingam et al., 2019). The overall low level of existing technology implementation within a company can also represent a significant hurdle. Many operations lack the IT networking infrastructure and data management abilities required for functional cyber-physical systems (Ratnasingam et al., 2019). Based on available resources, larger companies are often better placed to implement I4.0 strategies (Jäger and Lerch, 2020; Schröder, 2017). Due to a higher dependency on low-cost manufacturing in smaller companies, there has been restricted investments in technology in general (Ratnasingam et al., 2019).

The limited existing work describing wood products manufacturers suggests that overall awareness of I4.0 is low (Buehlmann et al., 2020) and, while companies are implementing various technologies, there are few that have moved significantly towards digitalization and comprehensive adoption of I4.0 (Kropivšek and Grošelj, 2020; Buehlmann et al., 2020). Just over half of large US secondary wood products manufacturers have a strategic vision in place for digitalization (Buehlmann et al., 2020).

Implementation of I4.0 can be thwarted because of an unwillingness to cooperate due to skills of workers and lack of budget (Müller et al., 2019). Along with the studies on the use of I4.0, there are initiatives in which organizations such as FPInnovations have created an FPinnovations Forestry 4.0 Initiative, which includes implementation of the rapidly growing fields of artificial intelligence (AI) and robotics (Gingras et al., 2020). Despite a growing literature base and initiatives such as that previously mentioned, there is significant need for insight into the current reality of I4.0 awareness and implementation in wood products manufacturing. This is especially the case for primary wood products manufacturers. While Müller et al. (2019) provide an overview of how I4.0 will change the forest value chain (standing trees to the mill gate) and Buehlmann et al. (2020) investigate secondary wood products manufacturing, little work addresses the context and situation with respect to primary wood products manufacturers.

\section{METHODS}

\section{METODE}

This study was conducted in four distinct phases. Phase 1 and Phase 2 were designed around information gathering, while Phase 3 involved developing and pilot testing a questionnaire. Finally, Phase 4 was a fullscale data collection among US primary wood products manufacturers. In detail, the four stages are: 1) secondary research using industry-focused trade journals, 2) interviews with key experts and representatives of equipment vendors to the industry, 3 ) an online survey serving as a pilot test of the questionnaire, and 4) a mail survey of primary wood products manufacturers in the U.S.

Phase 1: The purpose of Phase 1 was to identify current techniques and technologies documented in existing literature. Therefore, various international journals, papers and other publications were screened for I4.0 and smart manufacturing topics. Specifically, publications included were:

- Timber and Forestry e-news (Australia)

- Logging and Sawmilling Journal (North Vancouver, B. C., Canada)

- Timber West (Edmonds, WA, USA)

- International Forest Industries (Berkhamsted, United Kingdom)

- FDMC - Woodworking Network (Cedar Rapids, IA, USA)

- Wood Business - CFI (Canadian Forest Industries) (Simcoe, ON, Canada)

- OptiSaw Forum publications (Canada)

- Panel World (Montgomery, AL, USA)

- Timber Processing (Montgomery, AL, USA)

- Millwide Insider - the magazine from USNR (Woodland, WA, USA)

- AWISA (Australian Woodworking Industry Suppliers Association Limited) (Bowral, NSW, Australia)

The journals listed above were selected because they contain up-to-date information on technological advances in the wood products industry and its suppliers. Journal issues from 2016, 2017, and the first six months of 2018 were methodically examined for relevant information. This rather short period was considered adequate because of rapid technological change. Beyond the journals listed above, independent papers concerning the topic found on the internet were used to extend the compilation of the latest I4.0 developments. The findings of this phase were summarized to provide an overview of the technologies currently employed in wood products manufacturing. These results fed into the subsequent phases of the research.

Phase 2: In Phase 2, in-person visits were made to multiple machinery and equipment manufacturers in the Pacific Northwest region of the United States. Identification of site visits was partially informed by the previous phase and supplemented by knowledge of the research team. Twelve company technical personnel were interviewed from four different companies and five different locations. Questions asked during these visits addressed the techniques and technologies actively applied in the companies' production as well as their plans for development towards I4.0. Furthermore, general questions about technological advances in wood processing gave insight into the personal experience of the managers and their perception of the wood products industry. Facilities tours also helped inform the researchers of the use of 
technology and working methods. Insights gained from expert interviews were combined with results from Stage 1 to inform questionnaire development.

Phase 3: After gaining a better understanding of the state-of-the-art with respect to manufacturing techniques and technologies currently used by the wood products industry (results of Phases 1 and 2), a questionnaire was designed to assess the overall adoption of key I4.0 techniques and technologies as well as hurdles to implementing those technologies and techniques. All constructs were developed by the authors, specifically for this research. Questionnaire and survey design were conducted according to the principles of the Tailored Design Method (Dillman et al., 2014). The questionnaire consisted of 22 questions addressing the context of company operations, awareness of available technologies, use of available technologies, factors inhibiting implementation of technologies, resident expertise within the company, training conducted by the company, and finally, whether the company had a smart manufacturing or I4.0 strategy. These two key terms (i.e., I4.0 or Smart Manufacturing) were not used until the very last question given that it was assumed that many respondents would not be familiar with the terms. Instead, the manufacturing techniques and specific technologies were referenced, such as robotics and AI. The questions are shown in Table 1.

The questionnaire was pretested with employees of Oregon State University, resulting in small changes to question wording. Following this, a pilot test was conducted using all companies listed in the online Oregon Forest Industry Directory (www.orforestdirectory.com). An email was sent to each company (approximately $1800^{1}$ ) with a link to an online version of the questionnaire within the Qualtrics platform. The 58 valid responses from this pilot test were sufficient to show that the questionnaire and questions were working as designed. As expected, a very small number (4) claimed to have a smart manufacturing or I4.0 strategy, and each of these was a large company with over 500 employees.

\footnotetext{
Note that the directory database did not allow for filtering manufacturing firms from service providers, landowners, etc. Therefore, the actual target audience is a small fraction of this number.
}

Phase 4: The last phase of the research was a national mail survey of primary wood products manufacturers in the US. A list of mills was developed utilizing the 2018 Random Lengths Big Book. The following sectors were included: lumber (hardwood and softwood), plywood (hardwood and softwood), oriented strand board, engineered wood products, particleboard, and medium density fiberboard. This compilation resulted in a total of 444 mill sites. For each mill site, the mill manager was the target respondent. Where the Big Book did not provide mill manager contact information, attempts were made to call the company to identify the appropriate contact. Two attempts were made to contact each site. For those sites that we were unable to make contact, the questionnaire was sent to the "mill manager."

The survey process consisted of two waves of mailed questionnaires, with follow-up calls to non-respondents. A total of 47 questionnaires were returned due to bad addresses. Ninety-two usable responses were received resulting in an adjusted response rate of $22 \%$. To test for the potential presence of non-response bias, a total of 30 non-responding managers were called and asked four questions from the questionnaire. Their answers were compared to those of the 92 respondents using t-tests through SPSS. We found three significant differences $(\mathrm{p}<0.05)$ regarding expertise levels with respect to robotics and cloud computing suggesting that our respondents are likely more technologically savvy/oriented than the overall population. Knowledge of the terms Smart Manufacturing and Industry 4.0 was also different with respondents more likely to be familiar with the terms than non-respondents who primarily responded with no knowledge of the terms Smart Manufacturing and Industry 4.0. Additional analyses consisting of means and t-test comparisons $(\mathrm{p}<0.05)$ were also conducted using SPSS.

\section{RESULTS AND DISCUSSION}

\section{REZULTATI I RASPRAVA}

Most respondents manufacture lumber (61, which is equivalent to $71 \%$ of respondents), followed by plywood and veneer (8), OSB (8), engineered wood

Table 1 Study constructs and measurement

Tablica 1. Sadržaj upitnika i opis načina ocjenjivanja

\begin{tabular}{|c|c|c|c|}
\hline Question / Pitanje & $\begin{array}{c}\text { Rating scale } \\
\text { Ocjena }\end{array}$ & $\begin{array}{c}\text { Example item } \\
\text { Primjer }\end{array}$ & $\begin{array}{l}\text { Figure } \\
\text { in text } \\
\text { Slika } u \\
\text { tekstu }\end{array}$ \\
\hline $\begin{array}{l}\text { In which business sector is your location primarily } \\
\text { operating? } \\
\text { U kojem poslovnom sektoru primarno djelujete? }\end{array}$ & $\begin{array}{l}\text { Select all that apply } \\
\text { Odaberite sve što je } \\
\text { primjenjivo. }\end{array}$ & $\begin{array}{l}\text { Lumber; Plywood/Veneer } \\
\text { drvna građa; furnirska } \\
\text { ploča/furnir }\end{array}$ & \\
\hline $\begin{array}{l}\text { How many employees does your location employ? } \\
\text { Koliko radnika zapošljavate? }\end{array}$ & $\begin{array}{l}1-5 ; 6-10 ; 11-50 ; 51-100 \\
500+\end{array}$ & & \\
\hline $\begin{array}{l}\text { What is the level of awareness within your location } \\
\text { regarding these business/manufacturing technologies } \\
\text { and techniques? } \\
\text { Kolika je vaša svjesnost o navedenim poslovnim/ } \\
\text { proizvodnim tehnologijama i tehnikama? }\end{array}$ & $\begin{array}{l}\text { No awareness } 1-5 \text { High } \\
\text { awareness } \\
\text { niska svjesnost 1-5 } \\
\text { visoka svjesnost }\end{array}$ & $\begin{array}{l}\text { Robotics; Big Data } \\
\text { robotika; velike baze } \\
\text { podataka }\end{array}$ & 1 \\
\hline
\end{tabular}


Table 1 Study constructs and measurement (continuation)

Tablica 1. Sadržaj upitnika i opis načina ocjenjivanja (nastavak)

\begin{tabular}{|c|c|c|c|}
\hline Question / Pitanje & $\begin{array}{l}\text { Rating scale } \\
\text { Ocjena }\end{array}$ & $\begin{array}{l}\text { Example item } \\
\text { Primjer }\end{array}$ & $\begin{array}{l}\text { Figure } \\
\text { in text } \\
\text { Slika } u \\
\text { tekstu }\end{array}$ \\
\hline $\begin{array}{l}\text { For each of the issues below to what extent might the } \\
\text { techniques and technologies listed in the previous } \\
\text { question support your location? } \\
\text { Koliko bi vam za svaki od navedenih problema koristile } \\
\text { tehnike i tehnologije navedene u prethodnom pitanju? }\end{array}$ & $\begin{array}{l}\text { No support } 1-5 \text { Strong } \\
\text { Support } \\
\text { bez potpore } 1-5 \\
\text { snažna potpora }\end{array}$ & $\begin{array}{l}\text { Providing mass customiza- } \\
\text { tion; Increasing flexibility } \\
\text { pružanje masovne prila- } \\
\text { godbe; povećanje fleksibil- } \\
\text { nosti }\end{array}$ & 2 \\
\hline $\begin{array}{l}\text { To what extent do each of the following inhibit } \\
\text { implementation of the new manufacturing technologies } \\
\text { at your location? / U kojoj mjeri sljedeći navedeni uvjeti } \\
\text { sprečavaju implementaciju novih proizvodnih tehnologi- } \\
\text { ja u vašem pogonu? }\end{array}$ & $\begin{array}{l}1 \text { Not at all } \\
5 \text { To a great extend } \\
1 \text { nimalo } \\
5 \text { u velikoj mjeri }\end{array}$ & $\begin{array}{l}\text { Lack of skilled workers; No } \\
\text { roadmap for implementa- } \\
\text { tion / nedostatak kvali- } \\
\text { ficiranih radnika; nepo- } \\
\text { stojanje plana provedbe }\end{array}$ & 3 \\
\hline $\begin{array}{l}\text { Please indicate the level of expertise at your location in } \\
\text { each of the following fields. } \\
\text { Navedite razinu stručnosti u vašem pogonu u svakome } \\
\text { od sljedećih polja. }\end{array}$ & $\begin{array}{l}1 \text { Low level of expertise } \\
5 \text { High level of expertise } \\
1 \text { niska razina stručnosti } \\
5 \text { visoka razina stručnosti }\end{array}$ & $\begin{array}{l}\text { Data virtualization; Data } \\
\text { analysis } \\
\text { virtualizacija podataka; } \\
\text { analiza podataka } \\
\end{array}$ & 4 \\
\hline $\begin{array}{l}\text { Does your location provide employee training in any of } \\
\text { the following fields? } \\
\text { Osiguravate li osposobljavanje zaposlenika u bilo kojem } \\
\text { od sljedećih područja? }\end{array}$ & $\begin{array}{l}\text { Yes, No, Intent to in future } \\
\text { da, ne, plan za budućnost }\end{array}$ & $\begin{array}{l}\text { Robotics; Automation } \\
\text { robotika; automatizacija }\end{array}$ & \\
\hline $\begin{array}{l}\text { Does your location process and analyze collected } \\
\text { machine data to show the performance of production } \\
\text { (key performance indicators)? } \\
\text { Analizirate li prikupljene podatke o stroju kako biste } \\
\text { pratili svojstva proizvodnje (ključne pokazatelje } \\
\text { proizvodnje)? }\end{array}$ & $\begin{array}{l}\text { Yes, No } \\
d a, n e\end{array}$ & $\begin{array}{l}\text { Yes, for management Yes, } \\
\text { for real time production, } \\
\text { Yes but not real time, no } \\
\text { da, za upravljanje; da, za } \\
\text { proizvodnju u stvarnom } \\
\text { vremenu; da, ali ne } u \\
\text { stvarnom vremenu, ne }\end{array}$ & \\
\hline $\begin{array}{l}\text { Does your location use any form of virtual or augment- } \\
\text { ed reality? / Koristite li se bilo kojim oblikom virtualne } \\
\text { ili proširene stvarnosti? }\end{array}$ & $\begin{array}{l}\text { Yes, No } \\
d a, n e\end{array}$ & & \\
\hline $\begin{array}{l}\text { For what purpose does your location utilize cloud } \\
\text { services. } \\
\text { Za koju se svrhu koristite uslugama u oblaku? }\end{array}$ & $\begin{array}{l}\text { Select all that apply } \\
\text { Odaberite sve što je } \\
\text { primjenjivo. }\end{array}$ & $\begin{array}{l}\text { To increase mobility } \\
\text { povećati mobilnost }\end{array}$ & 5 \\
\hline $\begin{array}{l}\text { What IT-systems does your location currently utilize? } \\
\text { Kojim se IT sustavima trenutačno koristite? }\end{array}$ & $\begin{array}{l}\text { Select one or more } \\
\text { Odaberite jedan ili više }\end{array}$ & $\begin{array}{l}\text { Computer aided manufac- } \\
\text { turing / računalno potpo- } \\
\text { mognuta proizvodnja }\end{array}$ & 6 \\
\hline $\begin{array}{l}\text { What types of robotics are integrated in your produc- } \\
\text { tion? } \\
\text { Koje su vrste robotike integrirane u vašu proizvodnju? }\end{array}$ & $\begin{array}{l}\text { Select one or more } \\
\text { Odaberite jednu ili više. }\end{array}$ & $\begin{array}{l}\text { Substituting robots } \\
\text { zamjenski roboti }\end{array}$ & 7 \\
\hline $\begin{array}{l}\text { Does your location use any of the following operations } \\
\text { based on analysis of process data? } \\
\text { Koristite li se nekom od sljedećih operacija utemeljenih } \\
\text { na analizi procesnih podataka? }\end{array}$ & $\begin{array}{l}\text { Select one or more } \\
\text { Odaberite jednu ili više. }\end{array}$ & $\begin{array}{l}\text { Predictive maintenance } \\
\text { prediktivno održavanje }\end{array}$ & 8 \\
\hline $\begin{array}{l}\text { Does your location use remote servicing/maintenance? } \\
\text { Koristite li se servisiranjem/održavanjem na daljinu? }\end{array}$ & $\begin{array}{l}\text { Yes, No } \\
\text { da, ne }\end{array}$ & & \\
\hline $\begin{array}{l}\text { How does your location identify/track materials/ } \\
\text { products? } \\
\text { Kako identificirate/pratite materijale/proizvode? }\end{array}$ & $\begin{array}{l}\text { Select one or more } \\
\text { Odaberite jedan ili više. }\end{array}$ & ID barcode; RFID & 9 \\
\hline $\begin{array}{l}\text { Does your location apply the pay per use model } \\
\text { (Leasing of machines/products)? } \\
\text { Primjenjujete li model plaćanja po korištenju (leasing } \\
\text { strojeva/proizvoda)? }\end{array}$ & $\begin{array}{l}\text { Select one } \\
\text { Odaberite jedno. }\end{array}$ & $\begin{array}{l}\text { Yes we use it, No } \\
\text { da, primjenjujemo; } \\
\text { ne }\end{array}$ & \\
\hline $\begin{array}{l}\text { Does your location plan to invest in new manufacturing } \\
\text { technologies/techniques in the next three years? } \\
\text { Planirate li } u \text { sljedeće tri godine investirati u nove } \\
\text { proizvodne tehnologije/tehnike? }\end{array}$ & $\begin{array}{l}\text { Select One } \\
\text { Odaberite jedno. }\end{array}$ & $\begin{array}{l}\text { Yes we plan to, No } \\
\text { da, planiramo; ne }\end{array}$ & \\
\hline $\begin{array}{l}\text { What technologies would your location like to integrate } \\
\text { into operations but are too expensive? / Koje biste } \\
\text { tehnologije željeli integrirati u rad, ali su preskupe? }\end{array}$ & $\begin{array}{l}\text { Open Ended } \\
\text { otvorenog trajanja }\end{array}$ & & \\
\hline $\begin{array}{l}\text { Does your location have a smart manufacturing or } \\
\text { industry } 4.0 \text { strategy? / Imate li strategiju pametne } \\
\text { proizvodnje ili Industrije 4.0? }\end{array}$ & $\begin{array}{l}\text { Yes, No } \\
d a, n e\end{array}$ & & \\
\hline
\end{tabular}




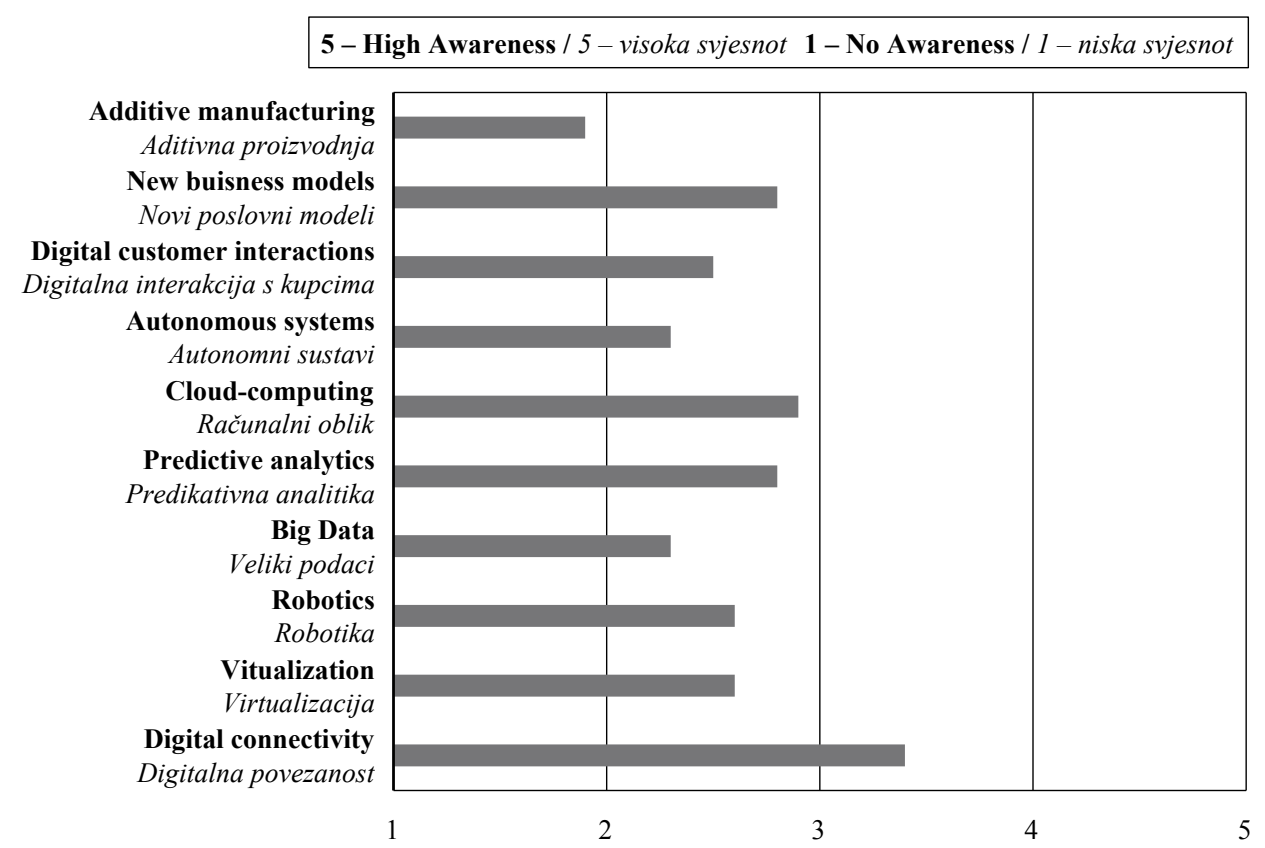

Figure 1 Level of awareness among respondents regarding various technologies $(n=89)$

Slika 1. Razina svjesnosti ispitanika o različitim tehnologijama $(n=89)$

products (3), non-structural panels (3), Particle board and MDF (6), "other" (2). With respect to size (based on mill site rather than entire company), the responding operations were: 1-5 employees (2), 6-10 employees (1), 11-50 employees (16), 51-100 employees (22), 101-500 employees (47), >500 employees (3). Therefore, $53 \%$ of responding mills had more than $100 \mathrm{em}-$ ployees at their site, while the remaining $47 \%$ had less than 100 employees.

The terms "smart manufacturing" or "Industry 4.0" were deliberately not used until the last question in the questionnaire, given the expectation that respondents would not be familiar with these terms. Further, the concern was that lack of familiarity might discourage participants from completing the questionnaire.
As expected, nearly $80 \%$ of respondents were unfamiliar with these terms, $89 \%$ of mills with 1-99 employees were unaware of the terms, while $75 \%$ of mills with over 100 employees were unaware of the terms and only six mills (each with more than 50 employees) stated that they had a smart manufacturing or I4.0 strategy. This level of awareness and implementation should be kept in mind when considering the results that follow.

Overall, awareness of technologies by respondents was quite low (Figure 1). As shown, there is a very low awareness regarding Additive Manufacturing (3D printing), Big Data, and Autonomous Systems. The highest level of awareness of technology is associated with Digital Connectivity, which can involve wireless

1 - No support / 1 - bez podrške $\mathbf{5}$ - High support / 5-snažna podrška

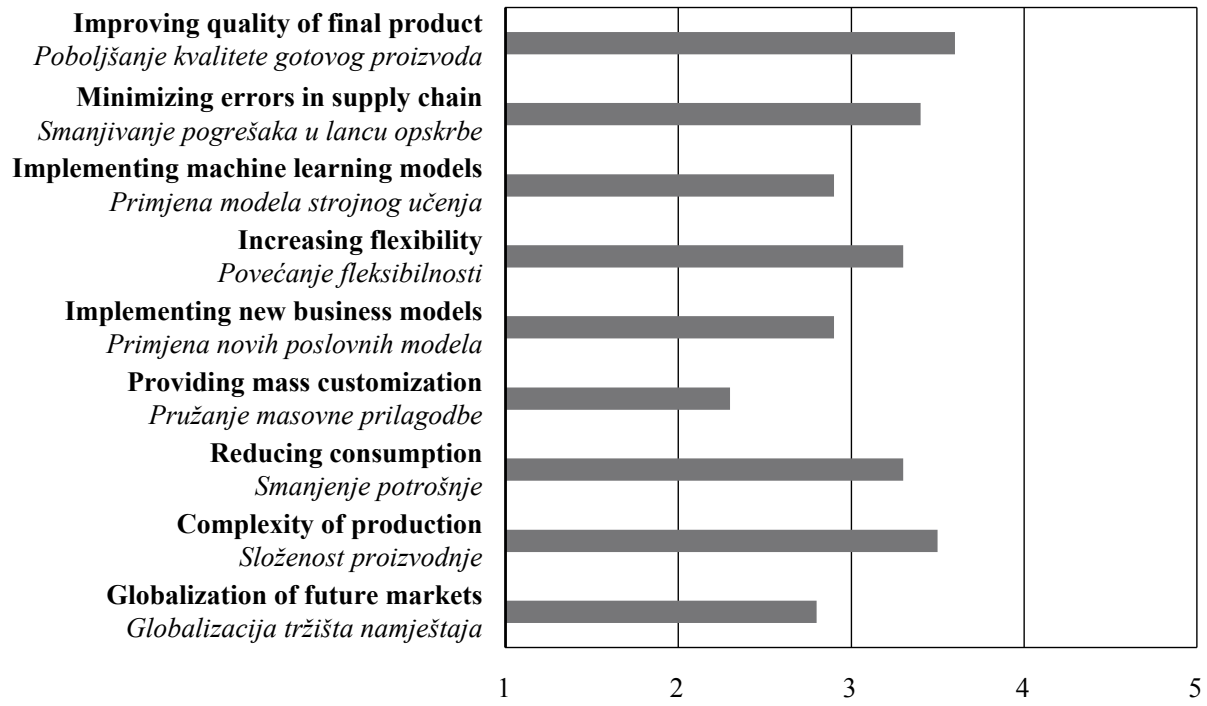

Figure 2 Perceived level of support provided by technologies listed in Figure $1(n=87)$

Slika 2. Percipirana razina potpore koju omogućuju tehnologije navedene na slici 1. $(n=87)$ 


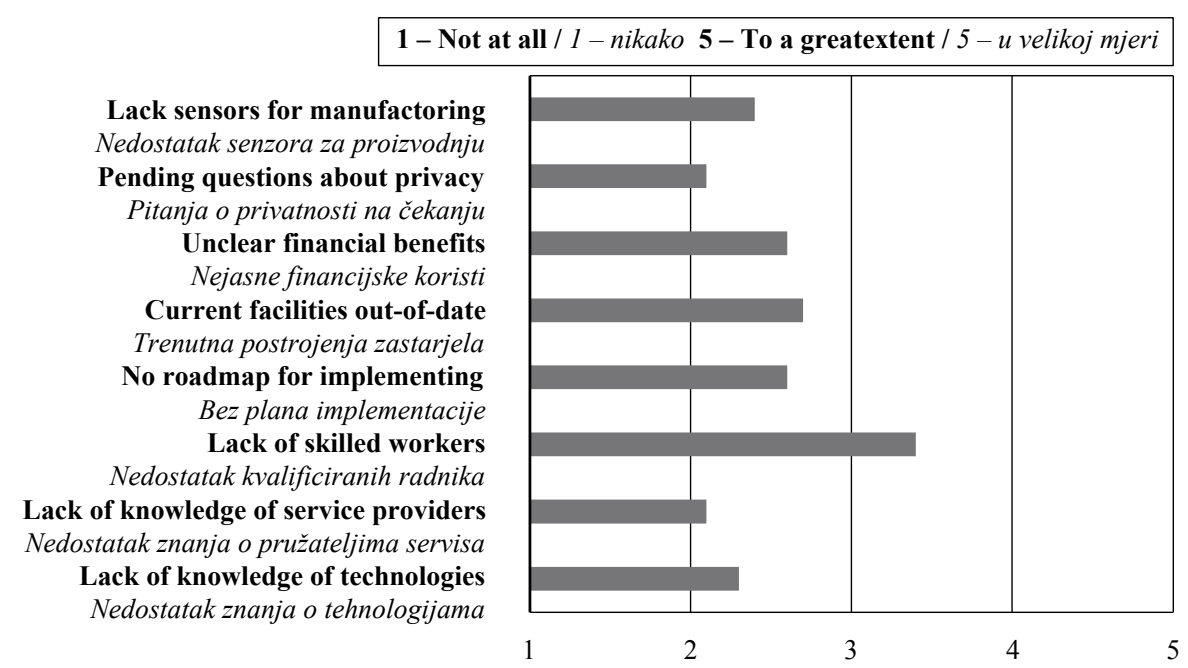

Figure 3 Factors perceived by respondent to inhibit implementation of new technology $(n=90)$

Slika 3. Čimbenici za koje ispitanik smatra da sprečavaju primjenu nove tehnologije $(n=90)$

networks and machine-to-machine connectivity (Castellina, 2018). Stronger awareness was also seen in cloud computing, new business models, and predictive analysis.

Based on the list of technologies shown in Figure 1, respondents provided their perception of how each might support their operation. Respondents did not perceive the technologies to provide a high level of support for their operations (Figure 2). Respondents were especially skeptical of the technologies helping with mass customization and dealing with globalization of future markets. They did expect some support for dealing with complexity of production and improving quality of final product.

Lack of a skilled workforce was seen as the biggest issue inhibiting implementation of new technologies (Figure 3). Other factors include current facilities being out-of-date, as well as no roadmaps for imple- mentation being available. The lack of knowledge of the services provided by new technologies was something respondents saw as a minor inhibitor to implementation.

More specifically, respondents indicated that the level of expertise within their staff on a variety of technologies was quite low (Figure 4). The highest level of expertise was in Manufacturing Process Monitoring and Data Analysis. The lowest level of expertise was in Robotics and Data Visualization. Although the level of awareness of robotics is high relative to other technologies, the ability of mills to implement robotics is low due to the low level of expertise.

Despite the low level of expertise, there appeared to be little appetite for training; less than half of respondents currently provide training on topics such as automation, data analysis and IT safety. Seven respondents reported intending to provide training in ro-

1 - No expertise / 1 - bez stručnosti 5 - High expertise / 5 - visoka stručnosti

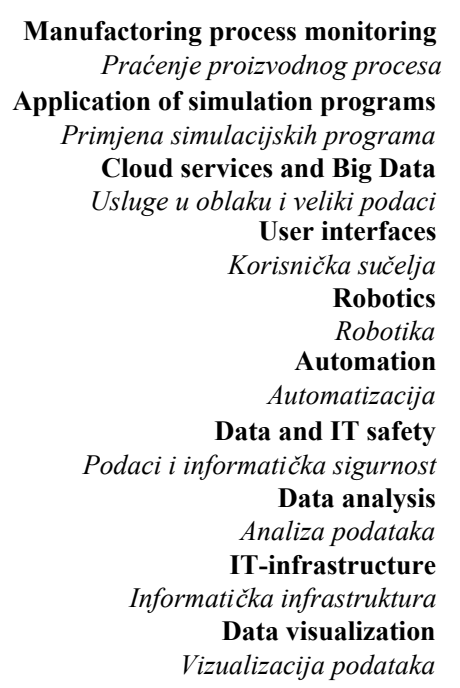

1

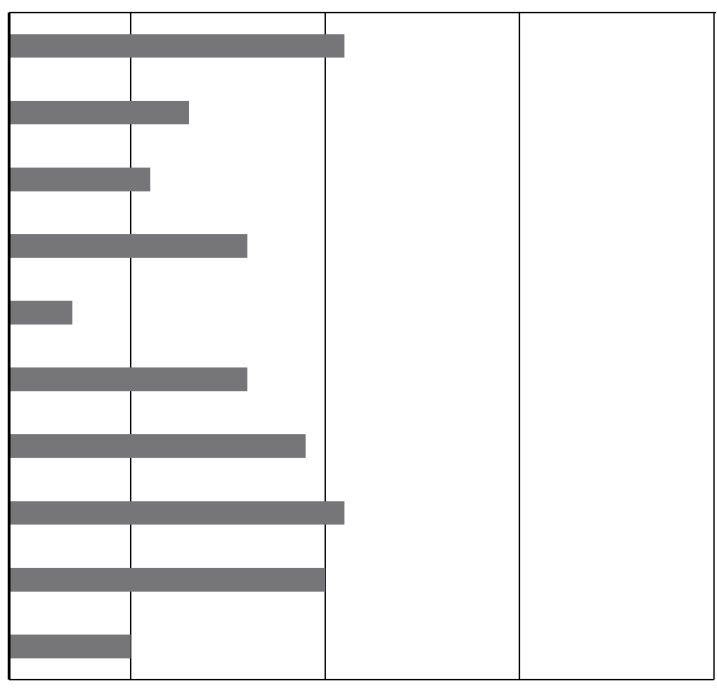

2

3

4

5

Figure 4 Level of expertise within respondent operations with respect to various technologies $(n=87)$

Slika 4. Razina stručnosti operacija u ispitanika s obzirom na različite tehnologije $(n=87)$ 


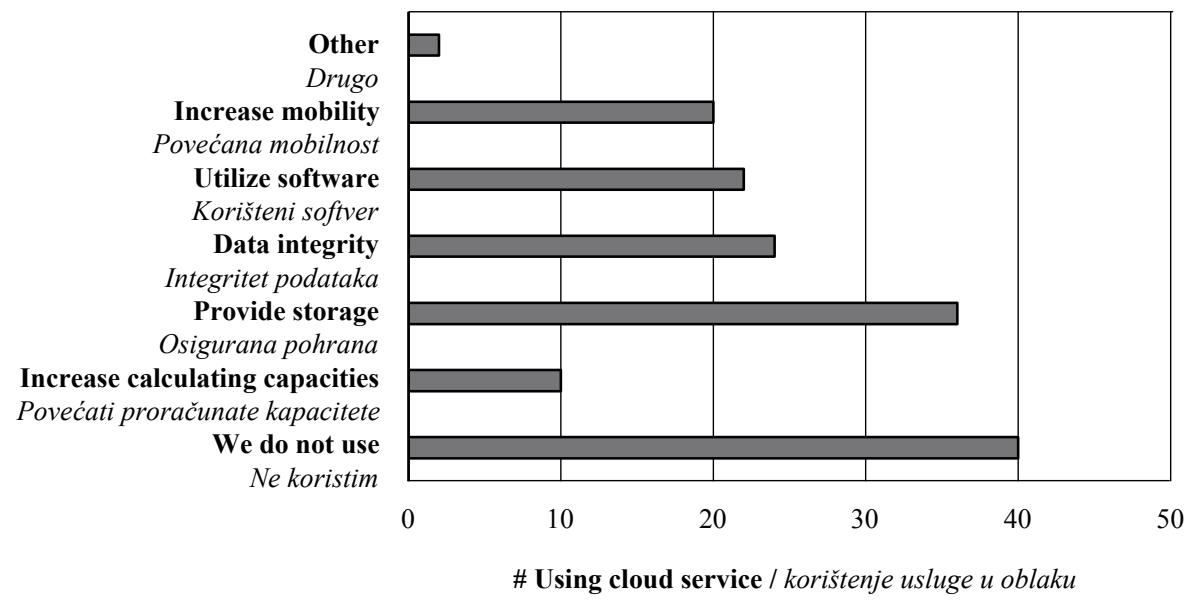

Figure 5 Use and application of cloud services by responding mills $(n=90)$

Slika 5. Korištenje i primjena usluga u oblaku kod ispitanika u pilanama $(n=90)$

botics in the future. Seven respondents reported the use of virtual reality in their operations. However, most of the examples provided by respondents do not qualify as virtual reality (e.g., display of processing position of $\operatorname{logs}$ ), providing further evidence of lack of familiarity with many of the techniques and technologies associated with I4.0.

The majority (40) of respondents stated they did not use cloud services for their operations (Figure 5). The greatest use of cloud services was providing storage with systems such as Google Drive and Dropbox. Very few mills (10) use cloud services to increase the computational capacities within mills.

Just over one-quarter of respondents use an enterprise resource planning platform in their operation (Figure 6). The highest use of IT-Systems is Computer Aided Design (CAD) with $48 \%$ of respondents reporting the use of CAD. This result was another red flag to the authors regarding awareness/knowledge since
CAD use in the primary wood products industry is typically limited to a few engineers needing to test new design concepts for mill layout or machinery. Twenty seven $(30 \%)$ respondents do not use any IT-systems in their operations.

Respondent operations are generally not employing robotics in their operations. Just over half claim that robotics would be useful in their operations (Figure 7). Another quarter of respondents claimed that they had no need of robotics. Of those employing robots, substituting robots was most common, followed by cooperative robots and automated guided vehicles (AGVs). As shown in Figure 4, expertise around robotics is very low, which contributes to the lack of use of robotics within production.

Our respondents actively analyze process data for the purposes of predictive maintenance, performance analysis, and decision-making, but are less commonly doing so for predictive quality manage-

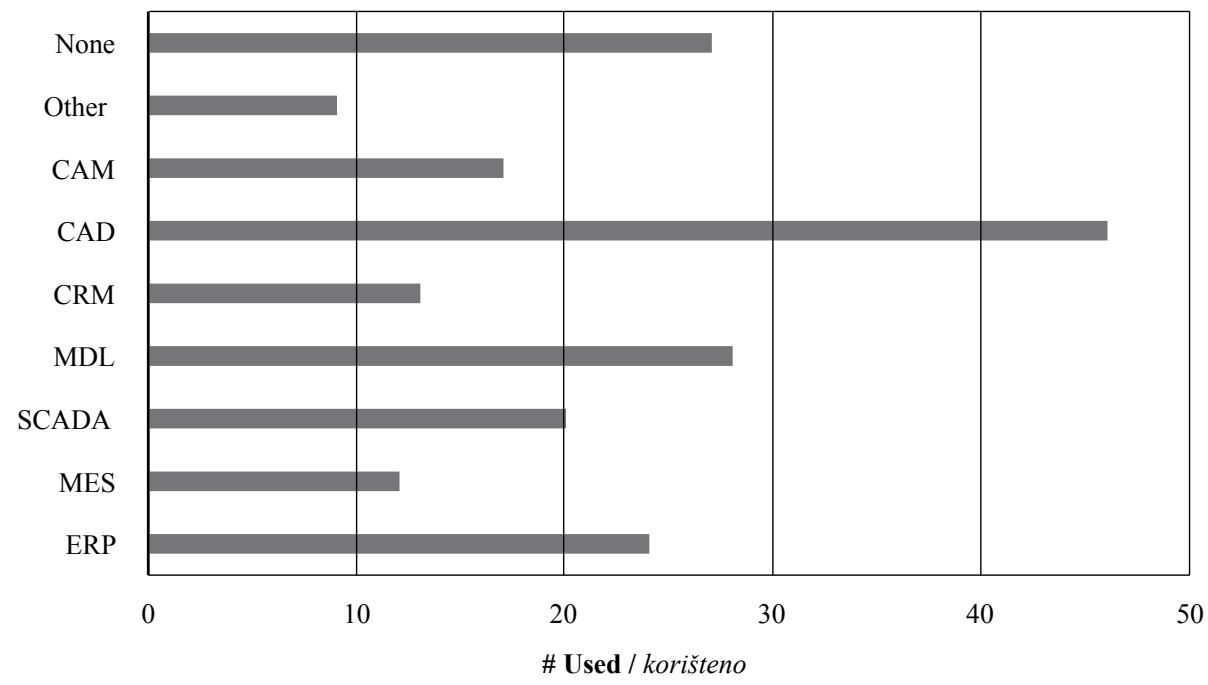

Figure 6 IT-Systems used by responding mills $(n=92)($ CAM - Computer Aided Manufacturing; CAD - Computer Aided Design; CRM - Customer Relationship Management; MDL - Machine Data Logging Systems, SCADA - Supervisory Control and Data Acquisition; MES - Manufacturing Execution System; ERP - Enterprise Resource Planning

Slika 6. IT sustavi kojima se koriste ispitanici u pilanama $(n=92)(C A M-$ računalom podržana proizvodnja; CAD - dizajn podržan računalom; CRM - upravljanje odnosima s kupcima; MDL - strojni sustavi za evidentiranje podataka, SCADA - nadzorna kontrola i prikupljanje podataka; MES - sustav izvršenja proizvodnje; ERP - planiranje resursa za poduzeća) 


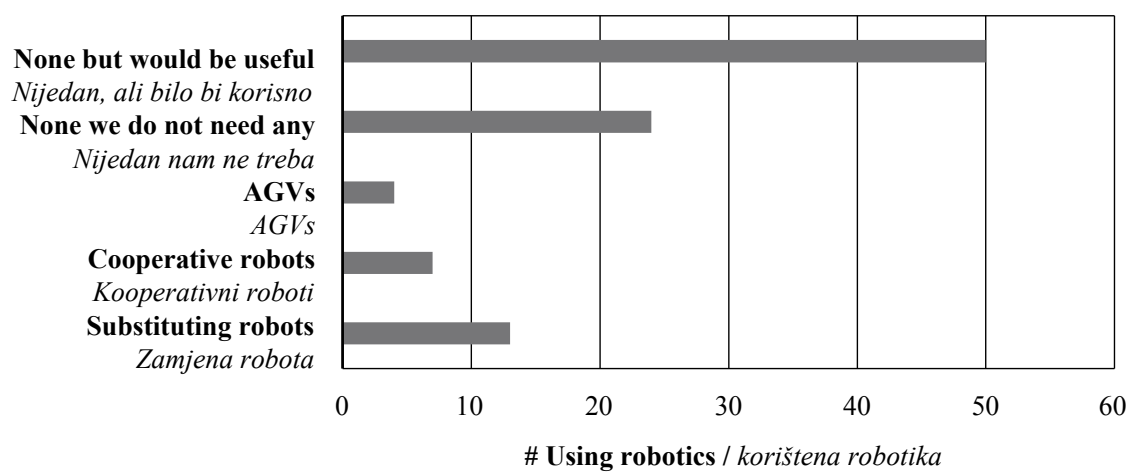

Figure 7 Types of robotics employed in respondent operations $(n=92)$ (AGVs - Automated Guided Vehicles) Slika 7. Vrsta robotike kojima se ispitanici koriste u operacijama $(n=92)$ (AGVs - automatizirano vođena vozila)

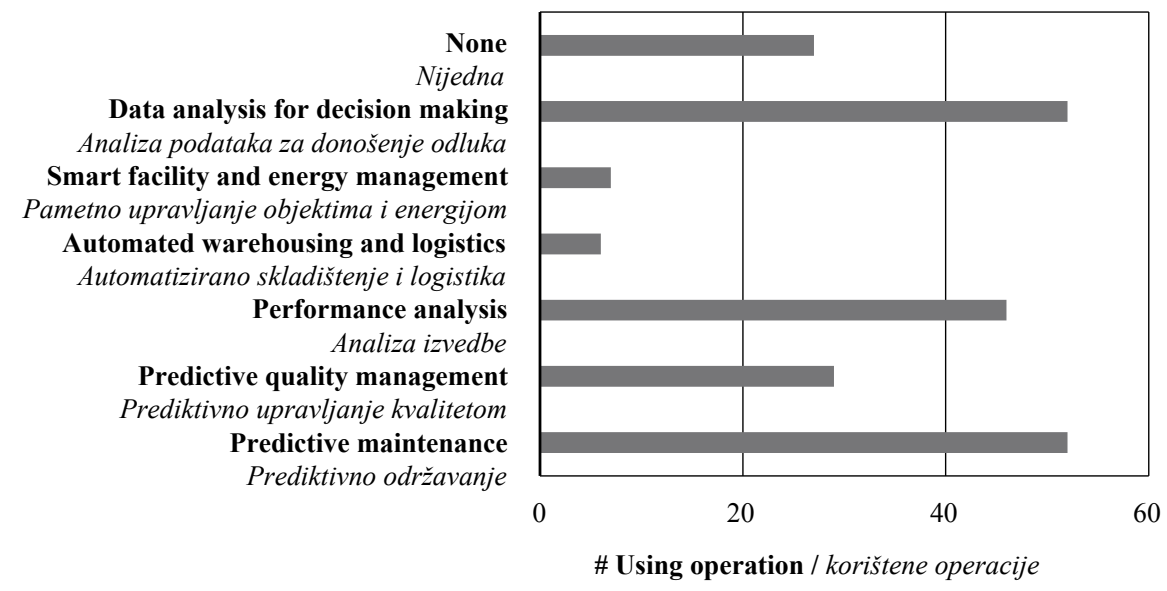

Figure 8 Activities supported by analysis of process data within respondent operations $(n=92)$

Slika 8. Aktivnosti podržane analizom procesnih podataka u operacijama ispitanika $(n=92)$

ment, automated warehousing and logistics, and smart facility and energy management (Figure 8).

Nearly half of respondents use remote servicing/ maintenance with an additional 15 that would use it if it were possible for them. Bar coding (1D - traditional linear type and $2 \mathrm{D}-\mathrm{QR}$ Code-type) was by far the most common method of tracking materials/products in respondent operations (57 mills; $61 \%$ ). Other tech- nologies such as RFID, photo ID, wood "fingerprint" detection and UV tags were, collectively, used by approximately $20 \%$ of respondents. Over $10 \%$ of respondents still use manual, paper-based methods of tracking (Figure 9).

Just under one-quarter $(22 ; 25 \%)$ of respondents reported using a pay-per-use model for accessing technologies. They are generally open to and looking to

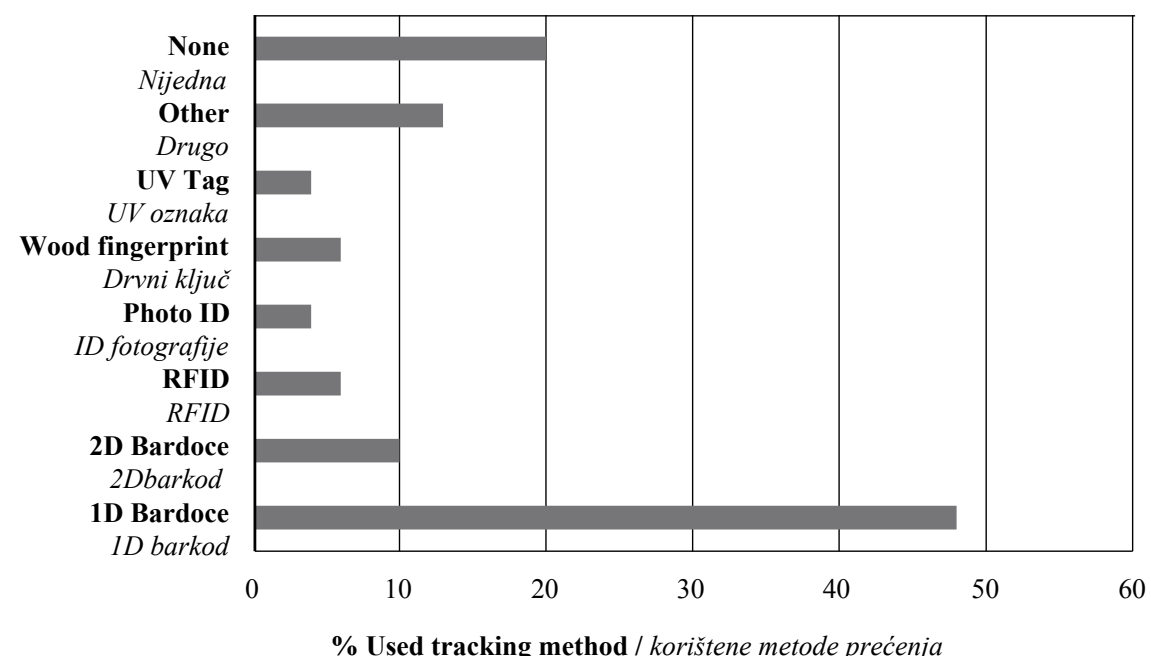

Figure 9 Methods used by respondents to identify and track materials $(n=88)$

Slika 9. Metode koje ispitanici primjenjuju za identificiranje i praćenje materijala $(n=88)$ 
invest in new technologies within the next three years. Seventy-one $(80 \%)$ respondents stated that they planned to invest in new technologies within the next three years, while only $19(21 \%)$ indicated no intention of investing in technologies.

One barrier to technology integration is cost. Respondents were asked to list technologies they would like to integrate into their operations but could not due to high costs. Of the $32(36 \%)$ respondents to this question, $11(12.5 \%)$ listed robotics and five (5.5\%) listed the use of automation in current technologies, such as lumber grading.

The connection between mill size and level and use of technologies is very prominent in the results. Dividing the mills into two size groups 1-100 (39) and $101-500(53)$, t-tests $(\mathrm{p}<0.05)$ showed that larger mills are more likely to have an overall higher awareness of techniques and technologies. The same pattern is true regarding levels of expertise. We suggest that larger mills have the resources to educate employees, resulting in a higher level of expertise.

\section{CONCLUSIONS}

\section{ZAKLJUČAK}

The results of the study show that adoption of I4.0 technologies within the primary wood products sector in the US is far behind what is possible. It is important to keep in mind that our non-response bias testing suggests our respondents are more technically oriented than non-respondents. Therefore, our statement above could likely be even stronger. Key hurdles to adoption of new technologies are a lack of skilled workforce and unclear financial benefits from an investment. As automation and digitization become requirements to stay competitive, the industry needs to accelerate its transition to I4.0. Therefore, awareness must be increased, or the industry in the US is in danger of losing competitiveness.

As suggested by Ratnasingam et al. (2019), research and policy work should take a careful look at the potential for moving the industry from current state of operations, which are largely within Industry 3.0, more fully to I4.0. Therefore, based on the results of this survey, an essential first step for the US primary forest products industry is to increase expertise through employee training. Companies stagnate if they do not have the required expertise within their workforce to adopt new technologies and there are few experts who are qualified and responsible to advocate and assist with adoption of advanced technologies. With a shortage of skilled labor in the market, it is not easy to hire new specialists, especially in the wood processing industry. Hiring from the outside may not be the best approach for businesses as it is more sustainable to upgrade the education of existing employees. Offering training to employees who already know the company ensures the best use of already existing technology and its application possibilities. Inclusion of existing employees may also serve to still the fear of what implementation of new techniques and technologies may bring, i.e., that automation, for example, is primarily about workforce reductions. Trainings should be offered through the entire transition and affected employees should be involved in process implementation because this is essential to build up commitment to new technologies. The most important factor for a successful digital change is that the employees understand the technologies they are going to work with. This is the only way companies will be able to maintain the new systems themselves. In the absence of employees that understand the technologies, companies are likely to forego plans to adopt new technology for fear they will not be successful in operation and maintenance.

The inhibiting factor of unclear (financial) benefits from an investment in new technology can also be eliminated by appropriate training for responsible experts and management. Measures to raise awareness should focus on various present and upcoming technologies and the company as a networked system. Results here showed that the majority of participants are convinced that new technologies would improve their production; however, they do not yet know critical details such as the technologies' effects on the production process and financial benefits. Hence, it is important to provide a personalized, systems-level overview about the technology and to illustrate different implementation scenarios within their range of possibilities and for their individual situation. In this way, companies will realize the use and necessity of some of the technologies for their production as well as the potential for increased profit. If adapted effectively for the individual business, implementation may have a short payback time that compensates for the cost of downtime during the switch to the new system. To tap the full potential of already implemented technology and to reveal financial benefits of possible investments, it is essential to identify the current state-of-the-art of the company as the basis for future operations.

Even before investing in employee training, companies might consider an online self-assessment of readiness for Industry 4.0 like that offered by FESTO, PwC or TÜV SÜD. FESTO's quick check for companies, for example, asks for general information about the company and lets the user choose relevant I4.0 targets for their company. The identification of the maturity level is based on questions in five different assessment categories. Additionally, the analysis includes corresponding recommendations for action (FESTO 2020). Based on such a current-state analysis, a next step for every company aspiring to I4.0 should be to develop a roadmap for a future technology strategy. It is important to take action as quickly as possible given the ever-increasing pace of technology adoption and development by competitors.

\section{REFERENCES}

\section{LITERATURA}

1. Basl, J., 2017: Pilot study of readiness of Czech companies to implement the principles of Industry 4.0. Manage- 
ment and Production Engineering Review, 8 (2): 3-8. https://doi.org/10.1515/mper-2017-0012.

2. Buehlmann, U.; Forth, K. D., 2020: Lack of a plan limits Industry 4.0 development for many companies. FDMC Magazine. May, 28-30.

3. Castellina, N., 2018: Networks: What digital connectivity means to manufacturers. available. https://www.manufacturing.net/industry40/article/13227930/networkswhat-digital-connectivity-means-to-manufacturers (Accessed Feb. 28, 2020).

4. Dillman, D. A.; Smyth, J. D.; Christian, L. M., 2014: Internet, phone, mail, and mixed-mode surveys: the tailored design method. John Wiley \& Sons. Hoboken, New Jersey, SAD.

5. Flores, M.; Maklin, D.; Golob, M.; Al-Ashaab, A.; Tucci, C., 2018. Awareness towards Industry 4.0: Key enablers and applications for Internet of things and Big Data. Collaborative Networks of Cognitive Systems, 377-386.

6. Gingras, J.; Charette, F.: FPInnovations' Forestry 4.0 Initiative. http://cofe.org/files/2017_Proceedings/FPInnovations $\% 20$ Gingras $\% 20$ Charette $\% 20$ Forestry $\% 20$ 4.0\%20for\%20COFE\%202017.pdf (Accessed: Mar. 2, 2020).

7. Jäger, A.; Lerch, C., 2020: Readiness for Industry 4.0, insights in the Upper-Rhine region. Fraunhofer Institute for Systems and Innovation Research ISI. Karlsruhe, Germany.

8. Kropivšek, J.; Grošelj, P., 2020: Digital development of Slovenian wood industry. Drvna industrija, 71 (2): 139148. https://doi.org/10.5552/drvind.2020.1961.

9. MacDougall, W., 2014: Industrie 4.0 - Smart manufacturing for the future. Germany Trade \& Invest, Berlin, pp. 39.
10. Müller, F.; Jaeger, D.; Hanewinkel, M., 2019: Digitization in wood supply - A review on how Industry 4.0 will change the forest value chain. Computers and Electronics in Agriculture, 162: 206-218.

https://doi.org/10.1016/j.compag.2019.04.002.

11. Ratnasingam, J.; Ab Latib, H.; Yi, L. Y.; Liat, L. C.; Khoo, A., 2019: Extent of automation and the readiness for Industry 4.0 among Malaysian furniture manufacturers. BioResources, 14 (3): 7095-7110.

12. Rüßmann, M.; Lorenz, M.; Gerbert, P.; Waldner, M.; Justus, J.; Engel, P.; Harnisch. M., 2015: Industry 4.0 - The future of productivity and growth in manufacturing industries. Boston Consulting Group.

13. Schröder, C., 2017: The challenges of Industry 4.0 for small and medium - sized enterprises. Rriedrich-EbertStiftung. Bonn, Germany, pp. 21.

14. Thoben, K. D.; Wiesner, S.; Wuest, T., 2017: "Industrie 4.0 " and smart manufacturing - a review of research issues and application examples. International Journal of Automation Technology, 11 (1): 4-16. https://doi.org/10.20965/ijat.2017.p0004.

15. ***FESTO, 2020: Festo Industry 4.0 Quick Check. https://ip.festo-didactic.com/I4.0QuickCheck/ (Accessed Jan. 1, 2020).

\section{Corresponding address:}

\section{BROOKLYN LEGG}

Oregon State University

104 Kerr Admin Building

Corvallis, Oregon 97331-2106, SAD

e-mail: leggb@oregonstate.edu 